\title{
Pengembangan Media Pembelajaran Matematika Interaktif Berbasis Powerpoint pada Materi Kerucut
}

\section{Puspita Ayu Damayanti' dan Abd. Qohar ${ }^{2}$}

1,2Pendidikan Matematika, Pascasarjana, Universitas Negeri Malang, Indonesia

Corresponding Author: abd.qohar.fmipa@um.ac.id'

DOI: http://dx.doi.org/10.15294/kreano.v10i2.16814

Received : November 16 2018; Accepted: November 30 2019; Published: December 42019

\begin{abstract}
Abstrak
Penelitian ini bertujuan untuk mengembangkan media pembelajaran interaktif berbasis powerpoint pada materi kerucut yang valid dan praktis. Model pengembangan yang digunakan adalah modifikasi model $4 \mathrm{D}$ yang dikembangkan oleh Thiagarajan, yaitu pendefinisian, perancangan, dan pengembangan. Hasil analisa kevalidan menunjukkan bahwa media memenuhi kriteria valid dengan rata-rata skor 3,32. Hasil analisis kepraktisan menunjukkan bahwa media dinyatakan praktis dengan kriteria rata-rata skor hasil observasi kegiatan pembelajaran 3,83 dan skor hasil angket siswa 3,43. Berdasarkan hasil analisis tersebut, media pembelajaran interaktif berbasis powerpoint dapat dinyatakan valid dan praktis.
\end{abstract}

\begin{abstract}
This study aims to develop powerpoint-based interactive learning media on the material of cone. The development model used is the modification of $4 D$ model developed by Thiagarajan, that is defining, designing, and developing. The results of the validity analysis showed that the media fulfill the valid criteria in average score of 3.32. The results of practical analysis showed that the media was practical in average score of observation result of learning activity 3.83 and score of student questionnaire result 3,43. Based on the results of the analysis, powerpoint-based interactive learning media was valid and practical.
\end{abstract}

Keywords: powerpoint-based interactive learning media; cone

\section{PENDAHULUAN}

Matematika merupakan ilmu yang harus dikuasai siswa. Matematika merupakan ratunya ilmu (Rahmah, 2013). Dengan kata lain, matematika diperlukan pada ilmu lain. Selain itu, matematika juga merupakan ilmu abstrak. Dalam pembelajaran yang bersifat abstrak, Guru dituntut untuk kreatif menggunakan berbagai media maupun teknik agar peserta didik memahami materi (Sutawidjaja dan Dahlan, 2014). Oleh karena itu diperlukan berbagai metode untuk membelajarkan matematika, terutama hal-hal yang bersifat abstrak.

Hasil observasi pembelajaran di sekolah menunjukkan bahwa banyak siswa mengala- mi kesulitan dalam memahami konsep matematika apabila tidak ada wujud atau representasi dari konsep tersebut. Hal ini dikarenakan hakikat matematika adalah ilmu abstrak. Oleh karena itu, perlu adanya perantara yang merepresentasikan atau memodelkan konsep matematika yang abstrak melalui benda fisik atau manipulatif sehingga dapat membantu siswa belajar matematika.

Perantara atau media dapat menerjemahkan pesan dari konsep matematika yang abstrak kepada siswa melalui pemodelannya. Media merupakan sarana komunikasi yang menghubungkan antara sumber dan penerima (Heinich et al, 2000). Media juga sebagai peralatan dan bahan pembelajaran yang 
digunakan guru dan siswa dalam kegiatan pembelajaran (Subanji, 2013). Media terdiri dari beberapa jenis. Terdapat enam kategori dasar media, yaitu teks, audio, visual, video, manipulatif, dan orang (Heinich et al, 2000). Teks merupakan karakter alfanumerik yang mungkin ditampilkan dalam berbagai format. Audio merupakan objek sebagai perantara yang dapat didengar. Visual merupakan objek sebagai perantara yang dapat dilihat. Video merupakan media memuat gerakan atau animasi. Manipulatif merupakan media tiga dimensi yang dapat dipegang dan dimanipulasi oleh siswa. Orang yang dikatakan sebagai media adalah orang yang menyimpan informasi (Hamdani, 2010).

Salah satu media yang mencakup aspek teks, visual, dan video adalah powerpoint. Powerpoint merupakan wizard-driven yang secara konseptual mudah digunakan (Wet, 2006). Powerpoint dapat membantu guru menyajikan materi yang dapat meliputi gambar, suara, bahkan membuat animasi. Hal ini sesuai dengan pendapat Wet (2006) bahwa dalam pembelajaran, teknologi dapat digunakan sebagai cara untuk menyajikan materi yang dapat diakses oleh siswa.

Dalam pembelajaran, powerpoint memiliki banyak manfaat. Aly, Elen, Willems (2004) menyebutkan bahwa powerpoint dapat membuat siswa lebih fokus dan menghindari gangguan sehingga siswa dapat belajar dengan lebih baik. Wet (2006) menyebutkan bahwa ketertarikan dan keterlibatan siswa dalam belajar meningkat ketika menggunakan powerpoint. Wet (2006) juga menyebutkan bahwa waktu yang diperlukan untuk pembelajaran dengan menggunakan powerpoint menjadi lebih sedikit. Sejalan dengan pendapat Borboa et al (2017) bahwa melalui powerpoint partisipasi siswa dapat ditingkatkan dan waktu belajar lebih bermakna.

Powerpoint juga memiliki kelebihan dalam desainnya. Terdapat beragam desain dan tampilan yang dapat diganti dengan mudah. Powerpoint dapat didesain sehingga siswa dapat berinteraksi melalui menu hyperlink (Wet, 2006). Hal ini sejalan depan pendapat Matheson et al (2002) bahwa presentasi menggunakan powerpoint menjadi interaktif dengan menggunakan hyperlink. menambahkan bah- wa action button dan hyperlink dapat digunakan untuk mendesain powerpoint sehingga siswa dapat memilih slide atau materi tertentu yang ingin dipelajari (Wet, 2006).

Salah satu materi dalam matematika yang memerlukan adanya media adalah kerucut. Siswa memerlukan objek nyata yang mengilustrasikan bagaimana menentukan luas permukan kerucut. Kerucut termasuk kedalam bangun ruang sisi lengkung. Kerucut merupakan suatu bangun ruang yang dibatasi oleh suatu daerah lingkaran dan suatu bisang lengkung yang simetris terhadap porosnya yang melalui titik pusat lingkaran tersebut (Suharjana, 2008). Kelebihan Powerpoint bisa digunakan untuk membantu siswa belajar kerucut. Hal ini karena dengan tampilan yang disediakan Powerpoint, konsep kerucut yang abstrak bisa lebih mudah diterima oleh siswa. Pada penelitian sebelumnya disampaikan bahwa media dengan animasi sangat menarik dan mampu meningkatkan motivasi siswa (Maskur et al, 2017). Kelebihan media powerpoint, selain mudah dibuat oleh guru, adalah mampu membangun animasi yang halus. Dengan demikian media ini diunggulkan sebagi media animasi yang mudah digunakan dan menghasilkan animasi yang baik. Berdasarkan uraian di atas, dilakukan penelitian dengan judul Pengembangan Media pembelajaran interaktif berbasis powerpoint pada materi kerucut yang valid dan praktis.

\section{METODE}

Pengembangan media pembelajaran dilakukan dengan mengacu pada model pengembangan 4D oleh Thiagarajan et al (1974). Langkah-langkah dalam pengembangan media adalah pendefinisian, perancangan, pengembangan, penyebaran. Tahap pendefinisian meliputi identifikasi masalah yang muncul dalam pembelajaran. Perancangan meliputi penyusunan media sesuai dengan kondisi pada hasil tahapan pendefinisian. Tahap pengembangan meliputi validasi ahli dan praktisi, serta uji coba dalam skala kecil. Validasi ahli dilakukan oleh dosen sedangkan validasi praktisi dilakukan oleh mahasiswa $\mathrm{S} 2$ pendidikan matematika. 
HASIL PENELITIAN DAN PEMBAHASAN

\section{Pendefinisian}

Tahap pendefinisian terdiri dari analisis awal-akhir, analisis siswa, analisis konsep, analisis tugas, dan penetapan tujuan pembelajaran. Pada tahap analisis awal-akhir dilakukan analisa masalah yang dihadapi dalam pembelajaran. Siswa sebenarnya lebih menyukai pembelajaran luas permukaan kerucut menggunakan media kertas/ fisik. Namun, prinsip pembelajaran luas permukaan kerucut yang seringkali berupa "trial and error" menyebabkan media kertas tidak efisien. Pada tahap ini peneliti menyimpulkan bahwa perlu adanya media pembelajaran. Pada tahap analisis siswa, dilakukan identifikasi karakteristik siswa yaitu kemampuan akademis siswa. Peneliti menyimpulkan bahwa kemampuan akademis siswa beragam.

Pada tahap analisis konsep, dilakukan identifikasi konsep yang akan dipelajari. Pada tahap ini peneliti menetapkan konsep luas permukaan kerucut untuk digunakan dalam media. Pada tahap analisis tugas, dilakukan identifikasi karakter fisik tugas-tugas siswa. Melalui analisis tugas diharapkan media yang dikembangkan tidak betentangan dengan bahan ajar lain yang biasa siswa gunakan. Pada tahap penetapan tujuan pembelajaran, dirumuskan tujuan pembelajaran berdasarkan hasil analisis tugas dan konsep.

\section{Perancangan}

Tahap perancangan terdiri dari penyusunan tes, pemilihan media, pemilihan format, dan desain awal. Tahap penyusunan tes menjembatani tahap pendefinisian dan perancangan. Pada tahap ini, tujuan pembelajaran dikonversikan kedalam langkah-langkah kegiatan untuk mencapai tujuan tersebut. Pada tahap pemilihan media, peneliti menetapkan media powerpoint. Media ini didesain interaktif sehingga siswa dapat berinterksi langsung dengan media.

Pada tahap pemilihan format, peneliti menetapkan media yang didesain dengan format yang menyerupai lembar kegiatan siswa untuk menemukan konsep tetapi disertai dengan animasi. Pada tahap desain awal, peneliti mulai membuat draft media yang akan di- kembangkan. Draft tersebut dikonsultasikan untuk mendapatkan media yang baik. Hasil draft tersebut digunakan sebagai dasar untuk membuat media interaktif berbasis powerpoint.

Media yang didesain dapat dilihat pada gambar-gambar di bawah ini.

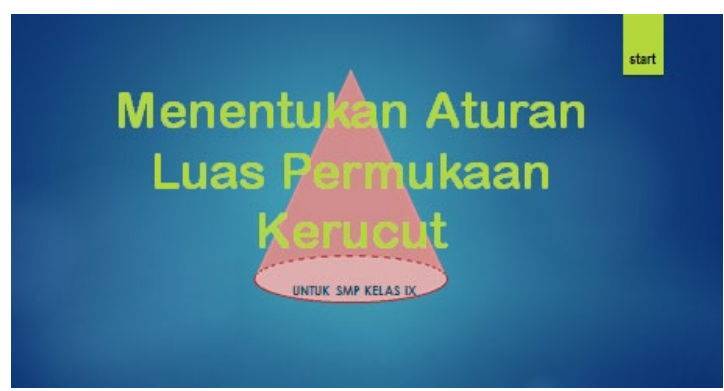

Gambar 1. Tampilan Awal

Halaman awal disusun sesuai dengan materi yang akan dipelajari. Peneliti memberikan tombol "start" untuk memulai penggunaan media.

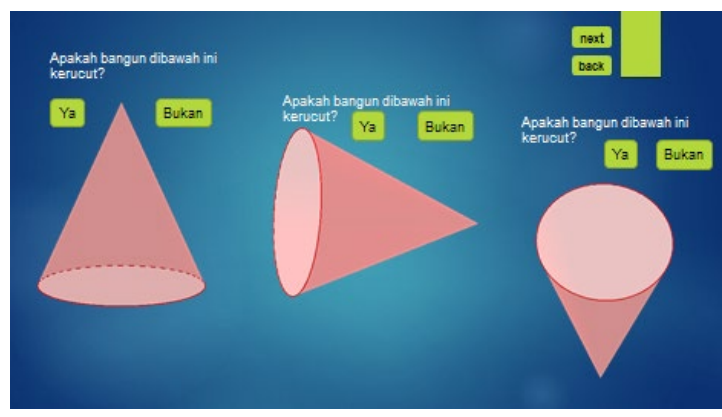

Gambar 2. Tampilan Apersepsi

Peneliti mendesain slide untuk apersepsi siswa yaitu dengan mengingat kembali makna kerucut. Peneliti memberikan tombol pilihan "ya" dan "tidak" di masing-masing pertanyaan dan pembahasan untuk tombol yang dipilih. Peneliti memberikan tombol "next" dan "back" pada pojok kanan atas slide. Tombol next untuk lanjut ke slide berikutnya sedangkan tombol back untuk kembali ke slide sebelumnya.

Peneliti juga memberikan slide yang memuat pertanyaan untuk mengarahkan siswa pada penemuan konsep. Siswa juga diberikan animasi selimut dan alas kerucut yang dibuka sehingga diperoleh aturan luas permukaan kerucut. 


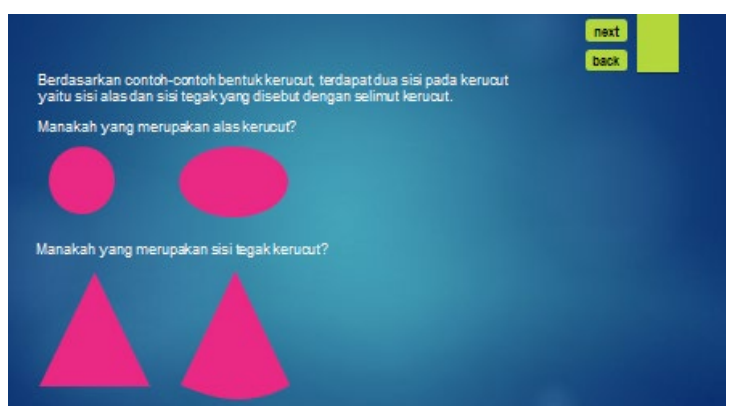

Gambar 3. Tampilan Pertanyaan yang Mengarah pada Konsep

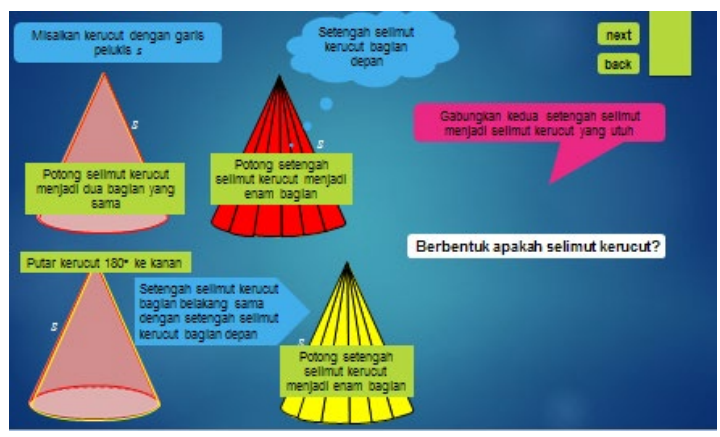

Gambar 4. Desain untuk Animasi pembukaan selimut kerucut

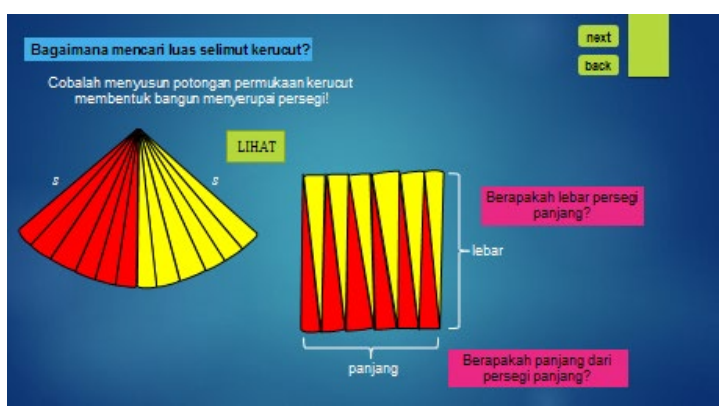

Gambar 5. Desain untuk menemukan aturan luas permukaan selimut

\section{Pengembangan}

Tahap pengembangan dilakukan untuk memodifikasi media berdasarkan hasil penilaian. Tahap pengembangan terdiri dari penilaian ahli dan uji coba skala kecil. Dalam penelitian ini, uji kevalidan dimaksudkan untuk menentukan kevalidan media yang dibuat serta saran untuk perbaikan media. Untuk selanjutnya, penilaian ahli disebut dengan validasi. Validasi dilakukan kepada dosen matematika dan mahasiswa S2 pendidikan matematika. Hasil validasi disajikan pada Tabel 1 berikut.
Tabel 1. Hasil Validasi Media

\begin{tabular}{|c|c|}
\hline Aspek & $\begin{array}{l}\text { Skor } \\
\text { Rata- } \\
\text { rata }\end{array}$ \\
\hline \multicolumn{2}{|l|}{ Isi Media Pembelajaran } \\
\hline $\begin{array}{l}\text { Media pembelajaran dapat membantu } \\
\text { siswa belajar matematika }\end{array}$ & $3 \cdot 5$ \\
\hline $\begin{array}{l}\text { Media pembelajaran dapat mem- } \\
\text { bantu siswa membangun pemahaman } \\
\text { matematika }\end{array}$ & 3 \\
\hline $\begin{array}{l}\text { Kegiatan yang diberikan memungkinkan } \\
\text { adanya interaksi yang positif antara siswa } \\
\text { dengan media pembelajaran }\end{array}$ & 4 \\
\hline $\begin{array}{l}\text { Kegiatan yang terdapat dalam penggu- } \\
\text { naan media pembelajaran sesuai dengan } \\
\text { tujuan pembelajaran }\end{array}$ & $3 \cdot 5$ \\
\hline $\begin{array}{l}\text { Media pembelajaran tidak menimbulkan } \\
\text { ambigu }\end{array}$ & 2.5 \\
\hline \multicolumn{2}{|l|}{ Gambar dan Animasi } \\
\hline $\begin{array}{l}\text { Media pembelajaran disertai dengan } \\
\text { gambar dan animasi yang sesuai dengan } \\
\text { materi atau konsep yang dibahas }\end{array}$ & $3 \cdot 5$ \\
\hline $\begin{array}{l}\text { Gambar dan animasi yang digunakan } \\
\text { memperjelas materi pembelajaran }\end{array}$ & $3 \cdot 5$ \\
\hline $\begin{array}{l}\text { Gambar dan animasi yang disajikan me- } \\
\text { narik }\end{array}$ & $3 \cdot 5$ \\
\hline $\begin{array}{l}\text { Gambar dan animasi yang disajikan ses- } \\
\text { vai dengan siswa SMP. }\end{array}$ & $3 \cdot 5$ \\
\hline \multicolumn{2}{|l|}{ Kegunaan Media Pembelajaran } \\
\hline $\begin{array}{l}\text { Dapat digunakan untuk membantu siswa } \\
\text { dalam mencapai tujuan pembelajaran }\end{array}$ & 3 \\
\hline $\begin{array}{l}\text { Dapat digunakan sebagai pendukung } \\
\text { pembelajaran matematika di sekolah }\end{array}$ & $3 \cdot 5$ \\
\hline Dapat mendorong siswa untuk lebih aktif & $3 \cdot 5$ \\
\hline \multicolumn{2}{|l|}{ Bentuk dan Tampilan } \\
\hline Tampilan media pembelajaran menarik & $3 \cdot 5$ \\
\hline Bentuk media proporsional & 3 \\
\hline Bahasa dan symbol & \\
\hline Bahasa yang digunakan komunikatif & $3 \cdot 5$ \\
\hline $\begin{array}{l}\text { Tampilan warna, jenis font, ukuran font } \\
\text { yang digunakan jelas terbaca }\end{array}$ & 3 \\
\hline $\begin{array}{l}\text { Tampilan warna, jenis font, ukuran font } \\
\text { yang digunakan menarik bagi siswa }\end{array}$ & 3 \\
\hline Rata-rata & 3,32 \\
\hline
\end{tabular}

Dari Tabel 1 diperoleh informasi bahwa media dinyatakan valid karena skor kevalidan diatas 3. Namun demikian validator memberikan komentar dan saran yang digunakan sebagai bahan pertimbangan untuk perbaikan.

Uji coba skala kecil, dalam penelitian 
ini, dimaksudkan untuk menentukan tingkat kepraktisan media. Media yang praktis setidaknya mudah digunakan dan dapat membantu siswa dalam memahami konsep luas permukaan kerucut. Penentuan kepraktisan media didasarkan pada hasil observasi kegiatan pembelajaran dan hasil angket siswa. Hasil observasi kegiatan pembelajaran disajikan pada Tabel 2 berikut.

Tabel 2. Hasil Observasi Kegiatan Pembelajaran

\begin{tabular}{lc}
\hline \multicolumn{1}{c}{ Aspek } & $\begin{array}{c}\text { Skor } \\
\text { Rata- } \\
\text { rata }\end{array}$ \\
\hline Pendahuluan & \\
\hline $\begin{array}{l}\text { Guru menggunakan apersepsi sesuai } \\
\text { dengan materi yang akan dipelajari }\end{array}$ & 4 \\
$\begin{array}{l}\text { Guru menyampaikan tujuan pembela- } \\
\text { jaran }\end{array}$ & 4 \\
$\begin{array}{l}\text { Siswa mengikuti kegiatan pendahuluan } \\
\text { Guru membagi siswa dalam beberapa }\end{array}$ & 4 \\
kelompok & 4 \\
\hline Kegiatan Inti & 4 \\
\hline $\begin{array}{l}\text { Guru mempersiapkan media pembela- } \\
\text { jaran yang digunakan }\end{array}$ & 4 \\
$\begin{array}{l}\text { Guru menjelaskan cara penggunaan } \\
\text { media pembelajaran }\end{array}$ & 3 \\
$\begin{array}{l}\text { Siswa terlibat dalam penggunaan me- } \\
\text { dia pembelajaran }\end{array}$ & 4 \\
$\begin{array}{l}\text { Siswa antusias dalam penggunaan } \\
\text { media pembelajaran }\end{array}$ & 3 \\
$\begin{array}{l}\text { Media dapat membantu siswa dalam } \\
\text { pembelajaran }\end{array}$ & 4 \\
\hline $\begin{array}{l}\text { Penutup } \\
\text { buru melajaran menarisanakan ina kegiatan refleksi }\end{array}$ & 4 \\
\hline Rata-rata & 4 \\
\hline
\end{tabular}

Data hasil observasi kegiatan pembelajaran menunjukkan bahwa skor mencapai 3,83 yang menunjukkan bahwa media mudah digunakan oleh Guru. Hasil angket respon siswa disajikan pada Tabel 3.

Hasil angket respon siswa menunjukkan bahwa skor mencapai 3,43 yang berarti respon siswa positif. Berdasarkan hasil observasi kegiatan dan angket siswa dapat dinyatakan bahwa media praktis.

Tabel 3. Hasil Angket Respon Siswa

\begin{tabular}{cc}
\hline & Skor \\
Aspek & Rata- \\
& rata
\end{tabular}

Penyajian Materi

Media pembelajaran matematika mudah saya gunakan

Penyajian masalah pada media pembelajaran matematika membantu saya me- $\quad 3.67$ mahami konsep matematika

Saya senang belajar matematika melalui media pembelajaran ini karena menarik

Media pembelajaran ini membuat saya ingin memahami matematika lebih lan- 3.11 jut

Media pembelajaran ini membuat saya lebih aktif

\begin{tabular}{lc}
\hline Bahasa dan Tampilan & \\
\hline $\begin{array}{l}\text { Petunjuk dan informasi yang disajikan } \\
\text { mudah saya pahami }\end{array}$ & 2.89 \\
Tampilan media pembelajaran menarik & 3.89 \\
Tampilan warna, jenis font, ukuran font & 3.33 \\
\hline yang digunakan jelas terbaca & 3,43 \\
\hline Rata-rata &
\end{tabular}

\section{Pembahasan}

Berdasarkan hasil validasi dan uji coba skala kecil dapat diketahui bahwa media pembelajaran interaktif berbasis powerpoint valid dan praktis. Kevalidan media didasarkan pada hasil validasi ahli dan praktisi. Validasi dari kedua validator diperoleh skor rata-rata 3,32 yang memenuhi kriteria valid. Meskipun demikian, validator memberikan komentar bahwa ilustrasi "pembukaan selimut kerucut" sudah cukup baik namun bisa dibuat lebih baik lagi.

Hasil uji coba skala kecil media powerpoint yang dikembangkan menunjukkan bahwa media dinyatakan praktis. Hasil observasi kegiatan pembelajaran mencapai skor ratarata 3,83 dan respon siswa positif yang mencapai skor rata-rata 3,33. Meskipun demikian, beberapa saran telah diberikan diantaranya adalah warna media yang kurang menarik dan bahasa yang digunakan dalam media terlalu tinggi untuk tingkat SMP sehingga siswa

\section{UNNDS JOURNALS}


kesulitan dalam memahaminya.

Media pembelajaran interaktif berbasis powerpoint didesain menyerupai lembar kerja untuk menentukan konsep luas permukaan kerucut. Konsep tidak disajikan secara langsung tetapi melalui pertanyaan yang mengarah pada penemuan konsep. Kegiatan ini mencerminkan bahwa siswa mengonstruk sendiri konsepnya. Siswa terlibat aktif sehingga pembelajaran lebih berhasil. Hal ini didukung hasil penelitian Jordan dan Papp (2014) bahwa powerpoint yang didesain sehingga siswa banyak berinteraksi dengan media dapat meningkatan pembelajaran.

Media berbasis powerpoint juga memuat animasi dalam menentukan luas selimut kerucut. Animasi yang diberikan juga disertai pertanyaan sehingga siswa tidak hanya menerima informasi tetapi juga ikut terlibat berpikir. Hal ini sejalan dengan hasil penelitian Davies et al (2016) bahwa pemberian animasi pada powerpoint dapat menjaga fokus dan keterlibatan siswa.

Secara umum, kelebihan media pembelajaran yang telah dikembangkan adalah membuat siswa terlibat aktif dalam penemuan konsep, dan memuat animasi membuka selimut kerucut sehingga menyerupai jajrgenjang yang cukup menarik. Namun demikian, media juga memiliki kekurangan, diantaranya bahasa yang digunakan sulit dipahami, dan belum memuat soal sebagai latihan siswa.

\section{PENUTUP}

\section{Kesimpulan dan Saran}

Media pembelajaran interaktif berbasis powerpoint yang dikembangkan telah valid dan praktis. Media layak digunakan dalam kegiatan pembelajaran dan mudah digunakan guru serta membantu siswa dalam memahami konsep. Media powerpoint terbatas pada materi kerucut khususnya luas permukaan kerucut. Oleh karena itu, peneliti selanjutnya dapat mengembangkan media pembelajaran interaktif berbasis powerpoint pada materi matematika yang lain. Materi yang membutuhkan media sebagai perantara.

\section{DAFTAR PUSTAKA}

Aly, M., Elen, J., \& Willems, G. (2004). Instructional multimedia program versus standard lecture: $\mathrm{A}$ comparison of two methods for teaching the undergraduate orthodontic curriculum. European Journal of Dental Education, 8, 43-46.

Borboa. D., Joseph, M. Spake, D., Yazdaparast, A. (2017). Perceptions and Use of Learning Management System Tools and Other Technologies in Higher Education: a Preliminary Analysis. Journal of Learning in Higher Education, 10(2) 17-23

Davies, T., Korte, L., Cornelsen, E. (2016). NonClassroom Use of "Presentation Software" in Accelerated Classes: Student Use and Perceptions of Value. Journal of Learning in Higher Education, 12(1) 37-43

Hamdani. (2010). Strategi Belajar Mengajar. Bandung: CV Pustaka Setia

Heinich, R., Molenda, M., Russel D.J., Smaldino, S.E., (2000). Instructional Media and Technologies for Learning. USA: Courier Kendallville, Inc.

Jordan, L \& Papp, R. (2014). Powerpoint: It's Not "Yes" or "No" - It's "When" and "How". Research in Higher Education Journal, 22

Matheson V.A., Abt-Perkins, D., Snedden, D. (2002). Making PowerPoint interactive with hyperlinks. Poster session presented at the annual American Economic Association Convention, Atlanta, GA

Maskur, R., Nofrizal, N., \& Syazali, M. (2017). Pengembangan Media Pembelajaran Matematika dengan Macromedia Flash. AlJabar: Jurnal Pendidikan Matematika, 8(2), 177-186.

Rahmah, N. (2013). Hakikat pendidikan matematika. Al-Khwarizmi: Jurnal Pendidikan Matematika dan Ilmu Pengetahuan Alam, 1(2), 1-10.

Subanji. (2013). Pembelajaran Matematika Kreatif dan Inovatif. Malang: UM PRESS

Suharjana, A. (2008). Mengenal Bangun Ruang dan Sifat-sifatnya di Sekolah Dasar. Yogyakarta: P4TK

Sutawidjaja, A., \& Dahlan, J. A. (2014). Pembelajaran matematika. Jakarta: UT Press.

Thiagarajan, S., Semmel, D.S., Semmel, M.I.(1974). Instructional Development for Training Teacher of Exceptional children: A SourceBook. Washington D.C: Indiana University

Wet, C.F. (2006). Beyond Presentations: Using PowerPoint as an Effective Instructional Tool. Gifted Child Today, 29(4) 29-39 